\title{
A duplex, SYBR Green I-based RT-qPCR assay for the simultaneous detection of Apple chlorotic leaf spot virus and Cherry green ring mottle virus in peach
}

Zhe Zhao ${ }^{1,2}$, Yun Yu' ${ }^{2}$, Zhixiang Zhang ${ }^{2}$, Pengbo Liang ${ }^{1,2}$, Yuxin $\mathrm{Ma}^{2}$, Shifang $\mathrm{Li}^{2}$ and Hongqing Wang ${ }^{1 *}$

\begin{abstract}
Background: Co-infections of Apple chlorotic leaf spot virus (ACLSV) and Cherry green ring mottle virus (CGRMV) in peach is common in China and have resulted in significant yield reductions. A reliable, sensitive and quantitive method is needed to detect and distinguish between ACLSV and CGRMV in peach.

Findings: We developed a sensitive and specific SYBR Green-I based RT-qPCR for the quantification of ACLSV and CGRMV in different peach tissues, and a duplex RT-qPCR system to detect ACLSV and CGRMV simultaneously. The RT-qPCR method was optimized using standard samples transcribed by the T7 Large Scale RNA Production System in vitro. The peach genes, RNA Polymerase subunit II (RPII) and Ubiquitin 10 (UBQ10), which were used as the internal controls for the quantification assay also showed good expression stability in this system. Single RT-qPCR assays showed that CGRMV in peach accumulates to a higher level than ACLSV. The detection limits of the duplex RT-qPCR assay were $10^{2}$ and $10^{4}$ copies for ACLSV and CGRMV, respectively. The sensitivity of the duplex RT-qPCR was as high as RT-qPCR and higher than RT-PCR.

Conclusions: The SYBR Green-I RT-qPCR assay provided a sensitive, specific and reliable method for the detection and quantification of ACLSV and CGRMV in different peach tissues. The duplex RT-qPCR system provided a sensitive and specific method to detect and differentiate between ACLSV and CGRMV in a single sample. This RT-qPCR assay could be a useful tool for the routine diagnosis of these two viruses and for disease epidemiology studies in peach orchards.
\end{abstract}

Keywords: ACLSV, CGRMV, SYBR Green I, Duplex real-time PCR, RT-qPCR

\section{Main text}

Apple chlorotic leaf spot virus (ACLSV) and Cherry green ring mottle virus (CGRMV) have been detected worldwide and display a broad host range on pome and stone fruit trees [1]. However, as ACLSV is present in infected trees at a low concentration [2], and the two viral infections are also normally latent in some stone fruits [2-4], a sensitive and effective system is needed to detect ACLSV and CGRMV in stone fruits. Multiple viral infections are common in stone fruit trees $[5,6]$. Field

\footnotetext{
* Correspondence: wanghq@cau.edu.cn

${ }^{1}$ College of Agronomy and Biotechnology, China Agricultural University, Yuanmingyuan West Road No. 2, Haidian District, Beijing 100193, People's Republic of China

Full list of author information is available at the end of the article
}

surveys of peach viruses showed that some peach trees were infected with both ACLSV and CGRMV in China (unpublished data). Recently, three articles have reported plant virus detection using multiple RT-qPCR assays [7-9]. Therefore, we initiated this study to develop a method to determine the absolute copy numbers of ACLSV and CGRMV genomes in peach tissues, and to evaluate a duplex SYBR Green I-based RTqPCR assay for the detection of ACLSV and CGRMV in a single reaction.

A total of 99 samples from leaf, branch bark, and flowers of peach infected with ALCSV and/or CGRMV and 34 leaf samples that showed mosaic symptoms were collected in China in 2012. Total RNAs were extracted

\section{Ciomed Central}


Table 1 Primer sequences and amplicon characteristics for PCRs

\begin{tabular}{|c|c|c|c|c|c|c|c|c|}
\hline $\begin{array}{l}\text { PCR } \\
\text { type }\end{array}$ & Name & $\begin{array}{l}\text { Locus } \\
\text { description }\end{array}$ & Primer Sequence $\left(5^{\prime}-3^{\prime}\right)$ & $\begin{array}{l}\text { Product size } \\
\text { (bp) }\end{array}$ & $\begin{array}{l}\text { Product } \\
\text { TM }\left({ }^{\circ} \mathrm{C}\right)\end{array}$ & $\begin{array}{l}\text { RT-qPCR } \\
\text { Efficiency (\%) }\end{array}$ & $\mathrm{R}^{2}$ & $\begin{array}{l}\text { Concentration } \\
\text { (nM) }\end{array}$ \\
\hline \multirow[t]{8}{*}{$\overline{q P C R^{a}}$} & AC62F & \multirow[t]{2}{*}{ Coat protein } & AAATACCCGGAGCTGATGTTTG & \multirow[t]{2}{*}{138} & \multirow[t]{2}{*}{$79.40 \pm 0.24$} & \multirow[t]{2}{*}{97.0} & \multirow[t]{2}{*}{0.9989} & 250 \\
\hline & AC62R & & CTTCGCCTCATTTCACTCTITG & & & & & 250 \\
\hline & CG732F & \multirow[t]{2}{*}{ Coat protein } & CAATTCAGGAGACGAACCCAG & \multirow[t]{2}{*}{181} & \multirow[t]{2}{*}{$81.44 \pm 0.37$} & \multirow[t]{2}{*}{101.0} & \multirow[t]{2}{*}{0.9939} & 250 \\
\hline & CG732R & & TTCCCGACCATCTTTGTTTG & & & & & 250 \\
\hline & RPIIF & \multirow{2}{*}{$\begin{array}{l}\text { RNA polymerase } \\
\text { subunit }\end{array}$} & TGAAGCATACACCTATGATGATGAAG & \multirow[t]{2}{*}{128} & \multirow[t]{2}{*}{$79.41 \pm 0.29$} & \multirow[t]{2}{*}{93.6} & \multirow[t]{2}{*}{0.9996} & 250 \\
\hline & RPIIR & & CTITGACAGCACCAGTAGATTCC & & & & & 250 \\
\hline & UBQ10F & \multirow[t]{2}{*}{ Ubiquitin 10} & AAGGCTAAGATCCAAGACAAAGAG & \multirow[t]{2}{*}{146} & \multirow[t]{2}{*}{$84.36 \pm 0.12$} & \multirow[t]{2}{*}{98.5} & \multirow[t]{2}{*}{0.9958} & 500 \\
\hline & UBQ10R & & CCACGAAGACGAAGCACTAAG & & & & & 500 \\
\hline \multirow[t]{4}{*}{$n P C R^{b}$} & $\mathrm{AC} 84 \mathrm{~F}$ & \multirow[t]{2}{*}{ Coat protein ${ }^{c}$} & TCTGCAAGAGAATTTCAGTT & \multirow[t]{2}{*}{777} & 1 & 1 & 1 & 1 \\
\hline & AC84R & & GTCTACAGGCTATTTATTATAAG & & 1 & 1 & 1 & 1 \\
\hline & CG94F & \multirow[t]{2}{*}{ Coat protein $^{d}$} & CCTCATTCACATAGCTTAGGTTT & \multirow[t]{2}{*}{929} & 1 & 1 & 1 & 1 \\
\hline & CG94R & & ACTTTAGCTTCGCCCCGTG & & 1 & 1 & 1 & 1 \\
\hline
\end{tabular}

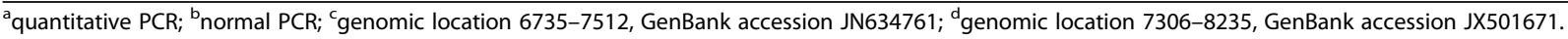
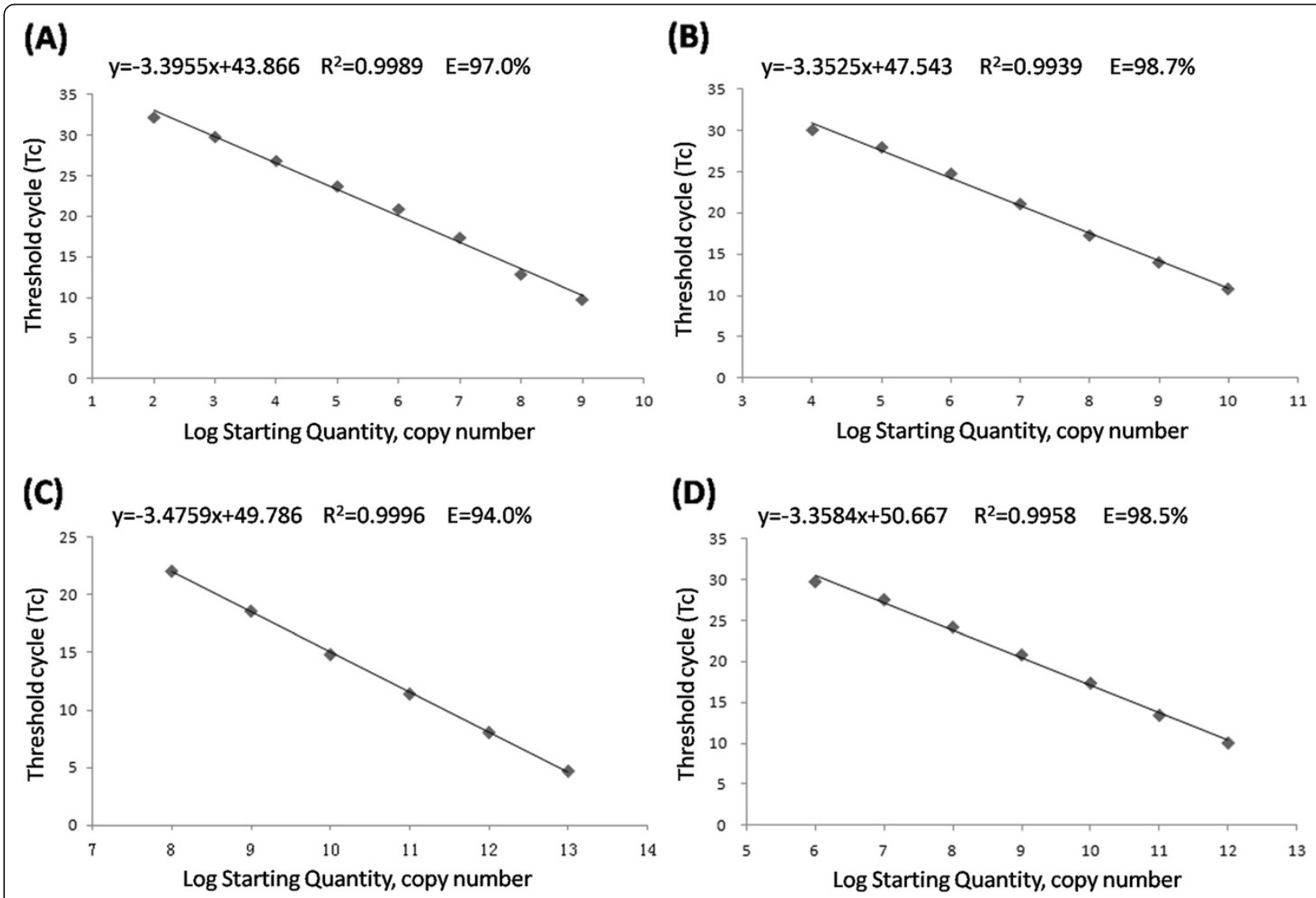

Figure 1 Standard curves for SYBR Green I-based real-time RT-PCR amplification of standard ACLSV, CGRMV, RPII and UBQ10 RNA with specific primer pairs (see Table 1). Amplification plots showing the testing in duplicate of a 10-fold dilution series containing (A) standard ACLSV RNA from $1.08 \times 10^{9}$ to $1.08 \times 10^{2}$ template copies/reaction, (B) standard CGRMV RNA from $1.13 \times 10^{10}$ to $1.13 \times 10^{4}$ template copies/ reaction, (C) standard RPII RNA from $2.09 \times 10^{13}$ to $2.09 \times 10^{8}$ template copies/reaction, and (D) standard UBQ10 RNA from $1.90 \times 10^{12}$ to $1.90 \times 10^{6}$ template copies/reaction. 
Table 2 ACLSV and CGRMV genomic RNA copy numbers in three peach tissues

Ct value $(X \pm \text { S.D. })^{a}[\text { Number of copies }(X \pm S . E .)]^{b}$

\begin{tabular}{llll} 
& ACLSV & CGRMV & RPII \\
\hline Leaf & $23.32 \pm 0.24^{\mathrm{c}}\left[1.12 \times 10^{6} \pm 1.82 \times 10^{5}\right]$ & $18.66 \pm 0.23^{\mathrm{f}}\left[4.07 \times 10^{8} \pm 4.17 \times 10^{7}\right]$ & $17.16 \pm 0.23^{\mathrm{i}}\left[2.45 \times 10^{9} \pm 2.64 \times 10^{8}\right]$ \\
Bark & $22.38 \pm 0.36^{\mathrm{d}}\left[2.14 \times 10^{6} \pm 5.13 \times 10^{5}\right]$ & $18.18 \pm 0.30^{\mathrm{g}}\left[5.62 \times 10^{8} \pm 6.92 \times 10^{7}\right]$ & $17.46 \pm 0.44^{\mathrm{j}}\left[2.04 \times 10^{9} \pm 4.16 \times 10^{8}\right]$ \\
Flower & $19.61 \pm 0.35^{\mathrm{e}}\left[1.38 \times 10^{7} \pm 3.31 \times 10^{6}\right]$ & $19.37 \pm 0.40^{\mathrm{h}}\left[2.51 \times 10^{8} \pm 6.92 \times 10^{7}\right]$ & $17.76 \pm 0.49^{\mathrm{k}}\left[1.68 \times 10^{9} \pm 3.78 \times 10^{8}\right]$ \\
\hline
\end{tabular}

aAverage threshold cycle (Ct) and standard deviation (S.D.) obtained from 33 different samples.

${ }^{\mathrm{b}}$ Average number of RNA copies (X) per sample and standard error (S.E.).

${ }^{c-n}$ Coefficient of variation (CV\%) between assays: $c=1.02, d=1.59, e=1.76, f=0.80, g=1.59, h=1.76, i=0.70, j=1.35, k=1.51, I=0.57, m=0.95, n=1.33$. 


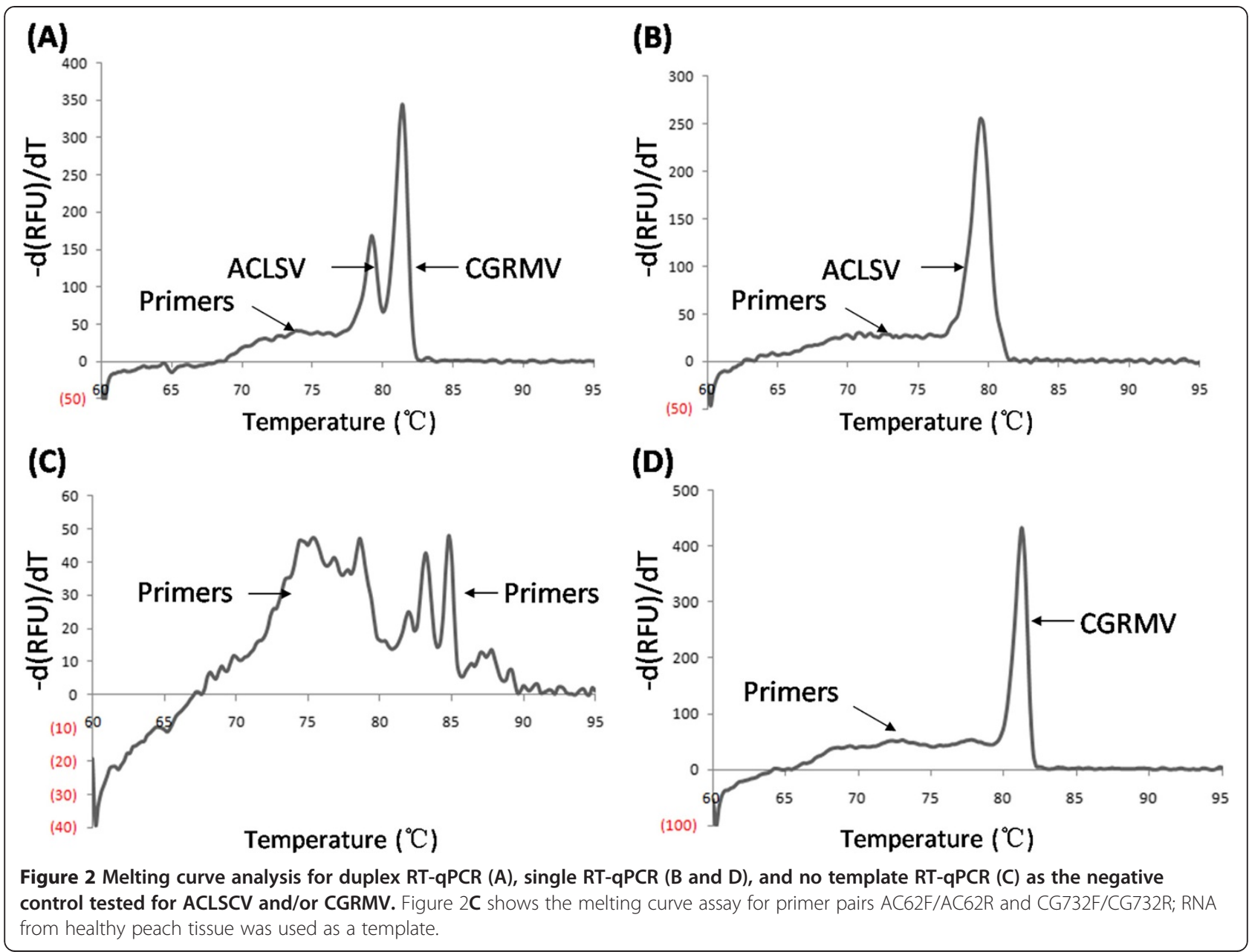

from the tissue samples using the RNAprep Pure Plant Kit protocol (Tiangene, Beijing, China). A spectrophotometer (NanoDrop Technologies, USA) was used to quantify the RNA samples and determine their quality (an $\mathrm{A}_{260} / \mathrm{A}_{280}$ ratio between 1.9 and 2.1, and an $\mathrm{A}_{260} /$ $\mathrm{A}_{230}$ ratio greater than 2.0).

Primer pairs AC84F/AC84R and CG94F/CG94R (Table 1) were used for normal PCR and predicted to amplify parts of the coat protein $(\mathrm{CP})$ gene fragment (genomic locations 6,735-7,512 and 7,306-8235, respectively) of ACLSV and CGRMV, respectively. Each amplified DNA fragment was purified using a PCR purification kit (Axygen, Hangzhou, China) and inserted into the pGEM-T vector (Promega, USA). Purified recombinant plasmid DNA was linearized by restriction enzyme cleavage before in vitro transcription. Positive-strand RNA was transcribed using the RiboMAX Large Scale RNA Production Systems-T7 Kit (Promega, Madison, WI, USA). A RNA purification protocol (Promega) was used to remove the DNA template.
The sequences of primers used in the RT-qPCR assay are listed in Table 1. Both sets of primers were tested against each other and other major peach viruses by RT-PCR, and all of the results were negative (data not shown). This indicated that both sets of primers are highly specific for the viral sequences from which they were designed.

Two internal control genes, RNA Polymerase subunit II (RPII) and Ubiquitin 10 (UBQ10) (peach EST database accession numbers TC1717 and TC2782, respectively), were used to evaluate the RT-qPCR assays as $U B Q 10$ and RPII are abundantly and constantly transcribed in all peach samples [10]. RNA extraction errors can be eliminated through the use of data analysis by the quantification of UBQ10 and RPII expression.

RNA templates for standard curves of the four genes were generated using the in vitro transcription method described by Zhang et al. in 2008 [11]. The purified RNA was quantified using the NanoDrop ND-1000 spectrophotometer (NanoDrop Technologies) and diluted 10-fold before use. One-step RT-qPCR reactions 
were performed using the GoTaq ${ }^{\circ}$ 1-Step RT-qPCR System (Promega) according to manufacturer's instructions. The final concentration of the AC62F, AC62R, CG732F, CG732R, RPIIF and RPIIR primers was 50 $\mathrm{nM}$, whereas UBQ10F and UBQ10R were used at 100 nM. All of these concentrations had good levels of amplification efficiency (Figure 1).

The analytical sensitivities or detection limits of single RT-qPCR assays were determined by amplifying sequential 10-fold dilutions of quantified standard RNA. Four RNA standard curves were generated with primers and templates using the protocol described above (Figure 1). The standard curves for ACLSV, CGRMV, RPII, and UBQ10 covered a linear range of eight, six, six and seven orders of magnitude (Figure 1A-D, respectively). The slopes and the correlation coefficients $\left(R^{2}\right)$ of the standard curves for ACLSV, CGRMV, RPII and UBQ10 were suitable, as shown as Figure 1. This finding indicated that both the target RNAs in infected peach tissue and the reference RNAs could be quantified by these assays. This assay system proved to be highly sensitive, and could be used to detect ACLSV starting with as little as $10^{2}$ copies, and $10^{4}$ copies at CGRMV.

Single RT-qPCR was used to quantify genomic RNA copies of ACLSV and CGRMV and mRNA copies of $R P I I$ and $U B Q 10$ in different peach tissues. RPII and UBQ10 mRNAs were quantified by this method to ensure that the assay system was reproducible. The number of copies per $100 \mathrm{ng}$ of total RNA was given in Table 2. The coefficient of variation $(\mathrm{CV})$ of the RPII and $U B Q 10$ assays (Table 1 ) showed a lower relative standard deviation, which suggested the RNA extraction and RT-qPCR methods were optimal for the quantification of ACLSV and CGRMV. This finding also showed that, as housekeeping genes, RPII and $U B Q 10$ were stably expressed genes across all of the tissues examined [10]. In the ACLSV assay, the copy numbers were $1.12 \times 10^{6} \pm 1.82 \times 10^{5}$ in leaf, $2.14 \times$ $10^{6} \pm 5.13 \times 10^{5}$ in bark and $1.38 \times 10^{7} \pm 3.31 \times 10^{6}$ in the flower. In the CGRMV assay, the copy numbers were $4.07 \times 10^{8} \pm 4.17 \times 10^{7}$ in leaf, $5.62 \times 10^{8} \pm 6.92 \times$ $10^{7}$ in bark and $2.51 \times 10^{8} \pm 6.92 \times 10^{7}$ in the flower. All data suggested that the absolute copy numbers of the ACLSV genome in leaf, bark and flower tissues of peach were lower than those of CGRMV. This result confirmed previous speculation regarding the low titer of ACLSV in stone fruit trees, and could to some extent explain the reason for the phenomenon of latent infection by ACLSV in stone fruits [2,3]. CGRMV has a relatively higher titer in bark, which was similar to the results found for Citrus tristeza virus in different citrus tissues [12], whereas the copy number of ACLSV is highest in flowers.
A duplex SYBR Green-I RT-qPCR assay was developed to address the observation that peach trees are often infected by both ACLSV and CGRMV (unpublished data). As shown in Figure 2A, ACLSV and CGRMV could be discriminated in a duplex RT-qPCR reaction by melting curve analysis of the specific

Table 3 Results of RT-PCR, single RT-qPCR and duplex RTqPCR detection of samples from different places infected with ALCSV and/or CGRMV

\begin{tabular}{|c|c|c|c|c|c|c|c|}
\hline \multirow[t]{2}{*}{ No. } & \multirow[t]{2}{*}{ Location } & \multicolumn{2}{|l|}{ RT-PCR } & \multicolumn{2}{|c|}{ Single RT-qPCR } & \multicolumn{2}{|c|}{ Duplex RT-qPC } \\
\hline & & ACLSV & CGRMV & ACLSV & CGRMV & ACLSV & CGRMV \\
\hline 1 & Qingdao & & + & & + & & + \\
\hline 2 & Qingdao & & & & & & \\
\hline 3 & Qingdao & & & + & & + & \\
\hline 4 & Qingdao & & & & & & \\
\hline 5 & Qingdao & & & & & & \\
\hline 6 & Qingdao & + & + & + & + & + & + \\
\hline 7 & Qingdao & & & & & & \\
\hline 8 & Qingdao & & & & + & & + \\
\hline 9 & Qingdao & & & & & & \\
\hline 10 & Qingdao & + & & + & & + & \\
\hline 11 & Qingdao & & & & & & \\
\hline 12 & Qingdao & & & + & & + & \\
\hline 13 & Qingdao & & & & & & \\
\hline 14 & Shijiazhuang & + & & + & & + & \\
\hline 15 & Shijiazhuang & & & & & & \\
\hline 16 & Shijiazhuang & + & & + & & + & \\
\hline 17 & Shijiazhuang & & & & & & \\
\hline 18 & Shijiazhuang & & + & & + & & + \\
\hline 19 & Shijiazhuang & & & & & & \\
\hline 20 & Shijiazhuang & & & & & & \\
\hline 21 & Shijiazhuang & & & & & & \\
\hline 22 & Shijiazhuang & & & & & & \\
\hline 23 & Taian & + & & + & & + & \\
\hline 24 & Taian & & & & & & \\
\hline 25 & Taian & & & & & & \\
\hline 26 & Taian & & & & & & \\
\hline 27 & Taian & & & & & & \\
\hline 28 & Taian & + & + & + & + & + & + \\
\hline 29 & Taian & & & & & & \\
\hline 30 & Taian & + & & + & & + & \\
\hline 31 & Taian & & & & & & \\
\hline 32 & Taian & & & & & & \\
\hline 33 & Taian & & & & & & \\
\hline 34 & Taian & + & + & + & + & + & + \\
\hline Total & & 8 & 5 & 10 & 6 & 10 & 6 \\
\hline
\end{tabular}


amplification products from the single RT- $\mathrm{PPCR}$ reactions. Specific melt peaks for ACLSV $\left(T=79.2^{\circ} \mathrm{C}\right)$ and CGRMV $\left(\mathrm{T}=81.4^{\circ} \mathrm{C}\right)$ were obtained from the duplex RT-qPCR (Figure 2A). Also, the amplification products observed in the duplex RT-qPCR reaction were amplified using single RT-qPCR assays and had nearly identical melting peaks: $79.6^{\circ} \mathrm{C}$ for ACLSV and $81.2^{\circ} \mathrm{C}$ for CGRMV (Figures $2 \mathrm{~B}$ and $\mathrm{D}$ ). It can be seen from Figure $2 \mathrm{~A}$ that the $-\mathrm{d}(\mathrm{RFU}) / \mathrm{dT}$ values for the ACLSVand CGRMV-specific DNA fragments in the duplex RT-qPCR assay were similar to those in single RTqPCR assays (Figures $2 \mathrm{~B}$ and $\mathrm{D}$ ), which indicated that the duplex assay can be used for the simultaneous detection of ACLSV and CGRMV. Healthy peach RNA (hpRNA) was used as the template in negative control (NC) reactions with the primer pairs AC62F/AC62R and CG732F/CG732R (Figure 2C). From this plot, the $\mathrm{d}(\mathrm{RFU}) / \mathrm{dT}$ value of the primers was lower than 50 , which was much lower than that of ACLSV or CGRMV, and showed a similar value to that shown in Figures $2 \mathrm{~A}, \mathrm{~B}$ and $\mathrm{D}$. The melting curve of the NC reactions with hpRNA and AC62F/AC62R or CG732F/ CG732R primers resulted in a similar curve to that shown in Figure $2 \mathrm{C}$ (data not shown). These results suggested that primer dimers did not affect the PCR assays, and also showed that both of the primer pairs used for ACLSV and CGRMV detection were highly specific. We collected 34 field peach samples showing mosaic symptoms that were suspected to be infected with ACLSV and/or CGRMV from three sites in China (Table 3). ACLSV was detected in eight samples by RTPCR and in ten samples by single and duplex RTqPCR; five samples were CGRMV-positive by RT-PCR and six samples by single and duplex RT-qPCR. This result showed that single and duplex RT-qPCR assays are more sensitive than normal RT-PCR, and as a stable and effective detection system, the duplex RTqPCR assay can be used to screen putatively infected peach trees in field.

Recently TaqMan-based multiplex RT-qPCR assays were used to detect viruses in tobacco, grapevine and rice [7-9]. SYBR Green-I multiplex RT-qPCR assays were developed for the simultaneous detection and quantification of animal viruses [13,14], and demonstrated that this strategy provides a reliable method for the detection and differentiation of nucleic acid targets. It also showed that multiple SYBR Green I-based RTqPCR assays can retain a high level of sensitivity required for detection. Here, we described the detection of plant viruses using SYBR Green-I RT-qPCR assays, which have the advantages of economical and rapid identification of desired target genes. The duplex RTqPCR assay and quantification of ACLSV and CGRMV titers in infected peach trees will provide a new method for the reproducible, sensitive and rapid detection of ACLSV and CGRMV. This will help to provide new insights into the biology of ACLSV and CGRMV that are necessary for disease control.

\section{Competing interests}

The authors declare that they have no competing interests.

\section{Authors' contributions}

$\mathrm{ZZ}$ designed the research, participated in the sequence alignment, analyzed data and drafted the manuscript. YY designed primers for the RT-qPCR assays, and collected virus samples. ZXZ carried out the optimization of the RT-qPCR assays, contributed to the design of the study, primer design, sample collection, statistical analysis and designing the duplex RT-qPCR protocol. PBL and YXM extracted RNAs from peach tissues. All authors read and approved the final manuscript.

\section{Acknowledgements}

This work was supported by grants from the Earmarked Fund for China Agriculture Research System (CARS-31), the Special Fund for Agro-scientific Research in the Public Interest (Nos. 201203076 and 200903004), the National Basic Research and Development Program of China (973 Program) (No. 2009CB119200) and the National Natural Science Foundation of China (Nos. 31171819 and 31000842).

\section{Author details}

${ }^{1}$ College of Agronomy and Biotechnology, China Agricultural University, Yuanmingyuan West Road No. 2, Haidian District, Beijing 100193, People's Republic of China. ${ }^{2}$ State Key Laboratory of Biology of Plant Diseases and Insect Pests, Institute of Plant Protection, Chinese Academy of Agricultural Sciences, Yuanmingyuan West Road No. 2, Haidian District, Beijing 100193, People's Republic of China.

Received: 6 May 2013 Accepted: 7 August 2013

Published: 10 August 2013

\section{References}

1. Sutic DD, Ford RE, Tosic MT: Virus diseases of fruit trees. In Handbook of plant virus diseases, 1st edn. CRC Press; 1999:345-347.

2. Polák J, Svoboda J: The reliability of detection and the distribution of Apple chlorotic leaf spot virus in pears in the Czech Republic. Hort Sci 2006, 33:7-10.

3. Ulubas C, Ertunc F: Apple Chlorotic Leaf Spot Virus (ACLSV) status in Turkey and sensitive detection using advanced techniques. Turk J Agric For 2005, 29:251-257.

4. Zhang YP, Kirkpatrick BC, Smart CD, Uyemoto JK: cDNA cloning and molecular characterization of cherry green ring mottle virus. J Gen Virol 1998, 79:2275-2281.

5. Jarošová J, Kundu JK: Simultaneous detection of stone fruit tree viruses by one-step multiplex RT-PCR. Sci Hortic 2010, 125:68-72.

6. Sanchez-Navarro JA, Aparicio F, Herranz MC, Minafra A, Myrta A, Pallas V: Simultaneous detection and identification of eight stone fruit viruses by one-step RT-PCR. Eur J Plant Pathol 2005, 111:77-84.

7. Dai J, Peng H, Chen W, Cheng J, Wu Y: Development of multiplex realtime PCR for simultaneous detection of three Potyviruses in tobacco plants. J Appl Microbio/ 2012. doi:10.1111/jam.12071.

8. López-Fabuel I, Wetzel T, Bertolini E, Bassler A, Vidal E, Torres LB, Yuste A, Olmos A: Real-time multiplex RT-PCR for the simultaneous detection of the five main grapevine viruses. J Virol Methods 2012. doi:10.1016/j. jviromet.2012.11.034.

9. Zhang P, Mar TT, Liu WW, Li L, Wang XF: Simultaneous detection and differentiation of Rice black streaked dwarf virus (RBSDV) and Southern rice black streaked dwarf virus (SRBSDV) by duplex real time RT-PCR. Virol J 2013, 10:24.

10. Tong Z, Gao Z, Wang F, Zhou J, Zhang Z: Selection of reliable reference genes for gene expression studies in peach using real-time PCR. BMC Mol Biol 2009, 10:71

11. Zhang $X$, Wang $X$, Zhou G: A one-step real time RT-PCR assay for quantifying rice stripe virus in rice and in the small brown planthopper (Laodelphax striatellus Fallen). J Virol Methods 2008, 151:181-187. 
12. Ruiz-Ruiz S, Moreno P, Guerri J, Ambrós S: A real-time RT-PCR assay for detection and absolute quantitation of Citrus tristeza virus in different plant tissues. J Virol Methods 2007, 145:96-105.

13. Pérez LJ, Perera CL, Frías MT, Núñez Jl, Ganges L, de Arce HD: A multiple SYBR Green I-based real-time PCR system for the simultaneous detection of porcine circovirus type 2, porcine parvovirus, pseudorabies virus and Torque teno sus virus 1 and 2 in pigs. J Virol Methods 2012, 179:233-241.

14. Pripuzova N, Wang R, Tsai S, Li B, Hung GC, Ptak RG, Lo SC: Development of Real-Time PCR Array for Simultaneous Detection of Eight Human Blood-Borne Viral Pathogens. PLoS One 2012. doi:10.1371/journal. pone.0043246.

doi:10.1186/1743-422X-10-255

Cite this article as: Zhao et al:: A duplex, SYBR Green I-based RT-qPCR assay for the simultaneous detection of Apple chlorotic leaf spot virus and Cherry green ring mottle virus in peach. Virology Journal 2013 10:255.

\section{Submit your next manuscript to BioMed Central and take full advantage of:}

- Convenient online submission

- Thorough peer review

- No space constraints or color figure charges

- Immediate publication on acceptance

- Inclusion in PubMed, CAS, Scopus and Google Scholar

- Research which is freely available for redistribution 